\title{
Heat-treated (in single aliquot or batch) colostrum outperforms non-heat-treated colostrum in terms of quality and transfer of immunoglobulin $\mathbf{G}$ in neonatal Jersey calves
}

\author{
A. A. Kryzer, ${ }^{* 1}$ S. M. Godden, ${ }^{*}$ and R. Schell† \\ *Department of Veterinary Population Medicine, University of Minnesota, St. Paul 55108 \\ †CalfStart LLC, Altura, MN 55910
}

\begin{abstract}
The objective of this randomized clinical trial was to describe the effect on colostrum characteristics and passive transfer of IgG in neonatal calves when using the Perfect Udder colostrum management system (single-aliquot treatment; Dairy Tech Inc., Greeley, CO) compared with a negative control (fresh refrigerated or fresh frozen colostrum) and a positive control (batch heat-treated colostrum). First-milking Jersey colostrum was pooled to achieve 31 unique batches with a minimum of $22.8 \mathrm{~L}$ per batch. The batch was then divided into 4 with $3.8 \mathrm{~L}$ allocated to each treatment group: (1) heat-treated in Perfect Udder bag at $60^{\circ} \mathrm{C}$ for $60 \mathrm{~min}$ and then stored at $-20^{\circ} \mathrm{C}(\mathrm{PU}) ;(2)$ heat-treated in a batch pasteurizer (Dairy Tech Inc.) at $60^{\circ} \mathrm{C}$ for $60 \mathrm{~min}$ and then stored at $-20^{\circ} \mathrm{C}$ in Perfect Udder bag (DTB; positive control); (3) fresh frozen colostrum stored at $-20^{\circ} \mathrm{C}$ in Perfect Udder bag (FF; negative control); and (4) fresh refrigerated colostrum stored at $4^{\circ} \mathrm{C}$ in Perfect Udder bag (FR; negative control). Colostrum from all treatments was sampled for analysis of $\operatorname{IgG}$ concentration and bacterial culture immediately after batch assembly, after processing, and before feeding. Newborn Jersey calves were randomly assigned to be fed $3.8 \mathrm{~L}$ of colostrum from 1 of the 4 treatment groups. A prefeeding, 0-h blood sample was collected, calves were fed by esophageal tube within $2 \mathrm{~h}$ of birth, and then a 24-h postfeeding blood sample was collected. Paired serum samples from 0- and 24-h blood samples were analyzed for $\operatorname{IgG}$ concentration $(\mathrm{mg} / \mathrm{mL})$ using radial immunodiffusion analysis. The overall mean IgG concentration in colostrum was $77.9 \mathrm{~g} / \mathrm{L}$ and was not affected by treatment. Prefeeding total plate counts $\left(\log _{10} \mathrm{cfu} / \mathrm{mL}\right)$ were significantly different for all 4 treatments and were lower for heat-treated colostrum $(\mathrm{PU}=4.23, \mathrm{DTB}=3.63)$ compared with fresh colostrum $(\mathrm{FF}=5.68, \mathrm{FR}=6.53)$. Total coliform counts
\end{abstract}

Received May 19, 2014.

Accepted November 23, 2014.

${ }^{1}$ Corresponding author: kryz0008@umn.edu $\left(\log _{10} \mathrm{cfu} / \mathrm{mL}\right)$ were also significantly different for all 4 treatments and were lower for heat-treated colostrum $(\mathrm{PU}=0.45, \mathrm{DTB}=1.08)$ compared with fresh colostrum $(\mathrm{FF}=3.82, \mathrm{FR}=4.80)$. Mean 24 -h serum IgG concentrations were significantly higher for calves in the PU $(41.0 \mathrm{mg} / \mathrm{mL})$ and DTB $(40.6 \mathrm{mg} / \mathrm{mL})$ groups compared with FF $(35.1 \mathrm{mg} / \mathrm{mL})$ and FR $(35.5 \mathrm{mg} /$ $\mathrm{mL}$ ) groups. Mean apparent efficiency of absorption of IgG was significantly higher for the PU (37\%) and DTB (37\%) groups compared with the FF $(32 \%)$ and FR (32\%) groups. Calves fed heat-treated colostrum (PU or DTB) experienced significantly improved AEA and serum IgG concentrations.

Key words: calf, colostrum, heat-treatment, passive transfer, immunoglobulin

\section{INTRODUCTION}

Colostrum is a critical source of nutrients and immune factors for newborn calves. However, colostrum can also represent one of the earliest potential exposures of dairy calves to a large variety of infectious agents including Mycoplasma spp., Mycobacterium avium ssp. paratuberculosis, fecal coliforms, Salmonella spp., and bovine leukemia virus (Steele et al., 1997; Walz et al., 1997; McGuirk and Collins, 2004). These pathogens can cause early calfhood morbidity or mortality caused by enteritis, septicemia, joint infections, or ear infections, or could contribute to chronic subclinical infections that are not clinically manifested until later in life (e.g., Johne's disease; Streeter et al., 1995; Steele et al., 1997; Walz et al., 1997). Additionally, high coliform counts in colostrum have been associated with decreased absorption of protective colostral immunoglobulins (James et al., 1981; Poulsen et al., 2002; Godden et al., 2012). In a recent nationwide survey of 67 farms in 12 states, $45.2 \%$ of colostrum samples tested had a total plate count $(\mathbf{T P C})>100,000 \mathrm{cfu} / \mathrm{mL}$ (Morrill et al., 2012). Experts recommend that fresh colostrum fed to calves has a TPC $<100,000 \mathrm{cfu} / \mathrm{mL}$ and a total coliform count (TCC) $<10,000 \mathrm{cfu} / \mathrm{mL}$ (McGuirk and Collins, 2004).

One management tool to reduce colostrum bacterial counts is that of heat-treating colostrum. Repeated 
studies have demonstrated that heating colostrum to $60^{\circ} \mathrm{C}$ for $60 \mathrm{~min}$ results in a significant reduction in bacterial count, with no differences seen in IgG concentration. Reduction of bacterial count reduces pathogen exposure while enhancing the efficiency of absorption of IgG (Johnson et al., 2007; Elizondo-Salazar and Heinrichs, 2010; Donahue et al., 2012), resulting in improved calf health. In a multiherd, randomized controlled field study, calves fed heat-treated colostrum were at lower risk of treatment for scours or of treatment for illness (any cause) in the preweaning period. In that study, pathway analysis suggested that calves fed heat-treated colostrum were healthier because the heat-treatment process caused a significant reduction in colostrum coliform counts, which was associated with reduced risk for illness as a function of improved serum IgG concentrations (Godden et al., 2012).

Despite the benefits of heat-treating colostrum, it is a relatively new technique that is not yet widely adopted on commercial dairy farms. One factor potentially limiting its adoption, particularly on small to mediumsized dairies, is the fact that only 1 or 2 cows may calve on a single day. As such, only 4 or $8 \mathrm{~L}$ of colostrum might need to be heat-treated on a given day. However, larger commercial batch pasteurizers typically require a minimum batch size of at least 8 to $16 \mathrm{~L}$. One potential solution to this problem is the development of a novel system designed to heat-treat individual 3.8-L aliquots of colostrum at a time. The Perfect Udder colostrum management system, developed by Dairy Tech Inc. (Greeley, CO), was designed to heat-treat individual 3.8-L aliquots of colostrum. Fresh colostrum is dispensed into a 3.8-L, single-use disposable bag, which is then floated in a batch pasteurizer tank of hot water or milk for heat treatment $\left(60^{\circ} \mathrm{C}\right.$ for $\left.60 \mathrm{~min}\right)$. After processing, the heat-treated colostrum can be cooled to feeding temperature and fed directly or refrigerated or frozen for later thawing and heating using a hot water bath-style thawing unit.

Although the Perfect Udder system, first introduced in 2011, appears to be a practical approach for allowing small and medium-sized dairies to heat-treat small volumes of colostrum, the process requires validation to ensure that colostrum is properly heat-treated (i.e., protecting colostral immunoglobulins while significantly reducing bacterial counts) and that the thawing process does not damage colostral IgG. Finally, calf feeding trials are needed to verify that calves fed colostrum heattreated using the Perfect Udder system experience the same increase in efficiency of absorption of IgG as those documented in previous studies that were fed colostrum heat-treated using a batch pasteurizer system.

The objectives of this study were to describe the effects of using the Perfect Udder colostrum manage- ment system to heat-treat bovine colostrum on (1) concentrations of bacteria and $\operatorname{IgG}$ in colostrum, and (2) efficiency of IgG absorption (\%) and serum IgG concentrations in neonatal dairy calves fed colostrum heat-treated using the Perfect Udder system compared with a negative control group (calves fed fresh colostrum) and a positive control group (calves fed traditional batch heat-treated colostrum). A secondary objective was to investigate the effect of storing fresh colostrum by refrigeration versus freezing on colostrum characteristics and on measures of passive transfer in calves.

\section{MATERIALS AND METHODS}

\section{Colostrum Processing and Sample Collection}

Study activities were approved by the University of Minnesota Institution of Animal Care and Use Committee (IACUC). The study was conducted during the summer of 2012 on a large commercial Jersey farm in Minnesota. The 6,000-cow system had approximately 20 calvings per day. First-milking colostrum was collected within $2 \mathrm{~h}$ of calving and stored for 8 to $10 \mathrm{~h}$ in the refrigerator until a minimum batch of $22.8 \mathrm{~L}$ could be assembled. Thirty-one unique batches were assembled for this study. Each batch was pooled and mixed thoroughly to ensure a consistent starting aliquot was obtained. Once the colostrum was thoroughly agitated, duplicate $10-\mathrm{mL}$ samples of fresh, raw colostrum were aseptically collected, labeled, and frozen at $-20^{\circ} \mathrm{C}$ (initial batch). The batch was then divided into 4 , with 3.8 $\mathrm{L}$ allocated to 1 of each of the following 4 treatments (Figure 1):

1. Perfect Udder system (PU): $3.8 \mathrm{~L}$ of colostrum was transferred into 1 Perfect Udder bag, and then heat-treated by floating in water in the DT10G (38 L) batch pasteurizer (Dairy Tech Inc.) at $60^{\circ} \mathrm{C}$ for $60 \mathrm{~min}$. Following cooling to $30^{\circ} \mathrm{C}$ or below, duplicate 10-mL samples of heat-treated colostrum were aseptically collected from the bag, labeled, and frozen at $-20^{\circ} \mathrm{C}$ (PU postprocessing). The 3.8-L bag of colostrum was then frozen at $-20^{\circ} \mathrm{C}$ for no less than $2 \mathrm{~d}$ before being selected for feeding. In preparing to feed, the bag was removed from the freezer and thawed in a hot water bath with water held at 48 to $51^{\circ} \mathrm{C}$. Once the colostrum was warmed to feeding temperature $\left(37-40^{\circ} \mathrm{C}\right)$, the colostrum was thoroughly agitated and duplicate $10-\mathrm{mL}$ samples of thawed colostrum were aseptically collected, labeled, and frozen at $-20^{\circ} \mathrm{C}$ (PU prefeeding).

2. Dairy Tech batch pasteurizer system (DTB; positive control): A minimum of $11.4 \mathrm{~L}$ of colostrum, 


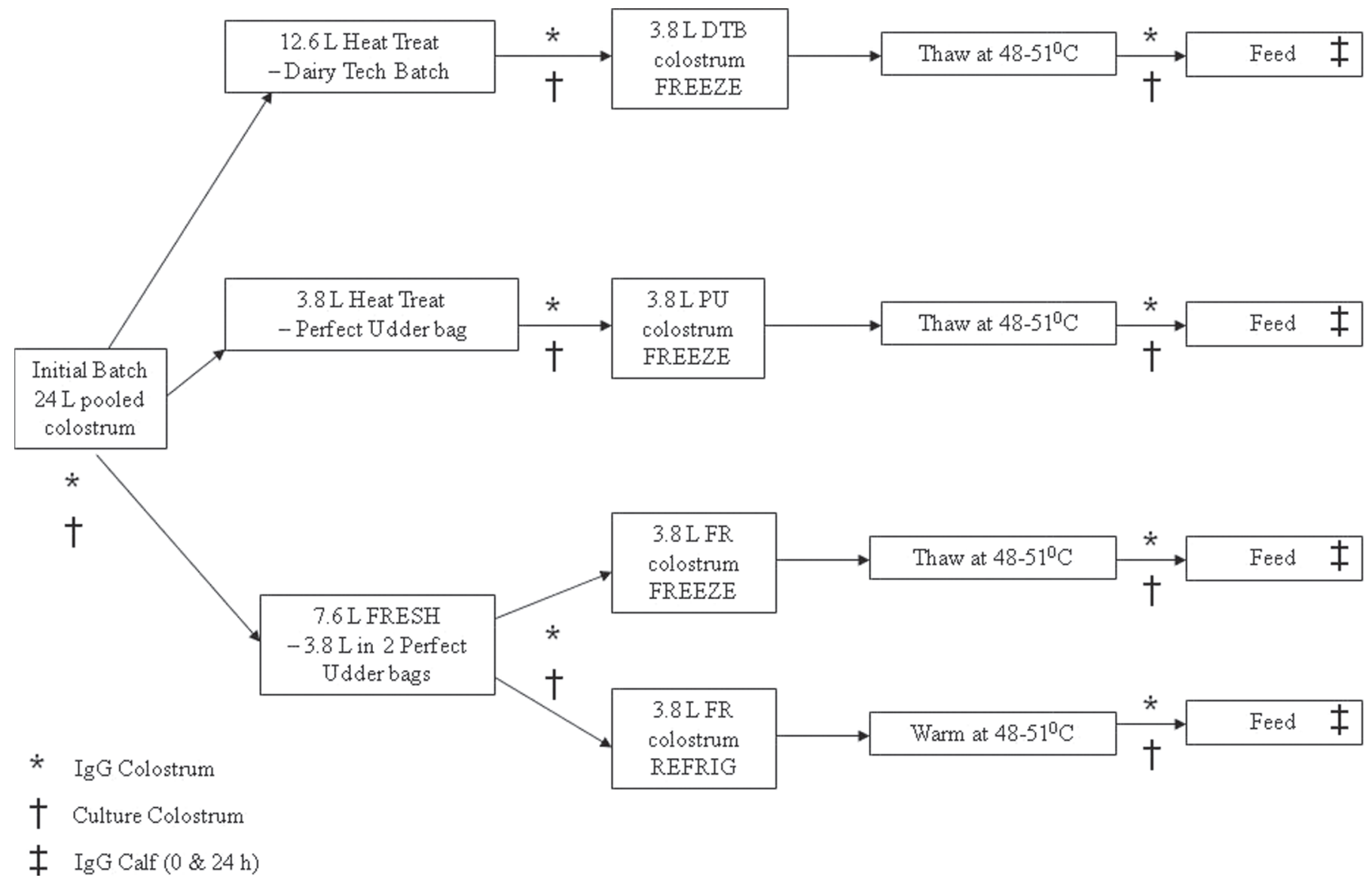

Figure 1. Colostrum treatment and sampling scheme for each of 31 batches of colostrum. Perfect Udder (PU) = heat-treatment of colostrum using the Perfect Udder Colostrum Management System (Dairy Tech Inc., Greeley, CO); Dairy Tech Batch = heat-treatment of colostrum using a commercial batch pasteurizer (Dairy Tech Inc.); FR = fresh colostrum (not heat-treated).

to meet the batch pasteurizer's minimum batch size, was transferred into the DT-10G batch pasteurizer system and heat-treated at $60^{\circ} \mathrm{C}$ for 60 min. Following cooling to $30^{\circ} \mathrm{C}$ or below, duplicate 10-mL samples of heat-treated colostrum were aseptically collected, labeled, and frozen at $-20^{\circ} \mathrm{C}$ (DTB postprocessing). Colostrum $(3.8 \mathrm{~L})$ was then transferred to a Perfect Udder bag and frozen in a chest freezer at $-20^{\circ} \mathrm{C}$ for no less than $2 \mathrm{~d}$ before feeding. In preparing to feed, the bag was removed from the freezer and thawed in a hot water bath with water held at 48 to $51^{\circ} \mathrm{C}$. Once the colostrum was warmed to feeding temperature $\left(37-40^{\circ} \mathrm{C}\right)$, the colostrum was thoroughly agitated and duplicate 10-mL samples of thawed colostrum were aseptically collected, labeled, and frozen at $-20^{\circ} \mathrm{C}$ (DTB prefeeding).

3. Fresh frozen colostrum (FF; negative control no. 1): $3.8 \mathrm{~L}$ of fresh colostrum was transferred into a Perfect Udder bag. Duplicate 10-mL samples of fresh colostrum were aseptically collected, labeled, and frozen at $-20^{\circ} \mathrm{C}(\mathrm{FF}$ postprocessing). The colostrum was then frozen in a chest freezer at $-20^{\circ} \mathrm{C}$ for no less than $2 \mathrm{~d}$ before being selected for feeding. In preparing to feed, the bag was removed from the freezer and thawed in a hot water bath with water held at 48 to $51^{\circ} \mathrm{C}$. Once the colostrum was warmed to feeding temperature $\left(37-40^{\circ} \mathrm{C}\right)$, the colostrum was thoroughly agitated and duplicate $10-\mathrm{mL}$ samples of thawed colostrum were aseptically collected, labeled, and frozen at $-20^{\circ} \mathrm{C}$ (FF prefeeding).

4. Fresh refrigerated colostrum (FR; negative control no. 2): $3.8 \mathrm{~L}$ of fresh colostrum was transferred into a Perfect Udder bag. Duplicate 10 -mL samples of fresh colostrum were aseptically collected, labeled, and frozen at $-20^{\circ} \mathrm{C}(\mathrm{FR}$ postprocessing). The colostrum was refrigerated in the Perfect Udder bag at $4^{\circ} \mathrm{C}$ for no more than $48 \mathrm{~h}$ before feeding. At that time, it was removed from the refrigerator and warmed in a hot water bath with water held at 48 to $51^{\circ} \mathrm{C}$. Once the 
colostrum was warmed to feeding temperature $\left(37-40^{\circ} \mathrm{C}\right)$, the colostrum was thoroughly agitated and duplicate 10-mL samples of thawed colostrum were aseptically collected, labeled, and frozen at $-20^{\circ} \mathrm{C}$ (FR prefeeding; Figure 1).

\section{Calf Enrollment and Sampling Schedule}

To be eligible for enrollment, newborn heifer calves had to be at least $22.7 \mathrm{~kg}$, from singleton birth, with a dystocia score of $\leq 3$ ( $1=$ unassisted, $2=$ easy pull, $3=$ moderate pull, $4=$ difficult pull, $5=$ caesarian section or torsion), have no obvious congenital abnormalities, and be removed from the maternity pen within 20 to 30 min of birth and before suckling. The calf was weighed using an electronic scale, individually identified using an ear tag, and then placed in a clean, well-bedded pen. A prefeeding $(0-1 \mathrm{~h}$ old $) 8-\mathrm{mL}$ blood sample was collected from the calf's jugular vein and into a red-top (serum separator) tube immediately before colostrum feeding. Calves were then randomly assigned $(\mathrm{n}=31$ calves per group, total $n=124$ ) to 1 of the 4 colostrum treatment groups.

After the first feeding of colostrum, calves were housed in a clean, well-bedded $3 \times 3 \mathrm{~m}$ group pen and fed a commercial $22 \%$ protein: $20 \%$ fat milk proteinbased milk replacer using a nipple bottle at $2 \mathrm{~L}$ twice daily until after $24 \mathrm{~h}$. At $24( \pm 1) \mathrm{h}$ of age, a second 8-mL venous "postfeeding" blood sample was collected from the jugular vein. After collecting the 24-h blood sample, calves were turned over to the regular care and feeding protocols used by the dairy.

\section{Colostrum Sample Handling and Analysis}

One of each pair of frozen colostrum samples from the initial batch, postprocessing, and prefeeding samples from each batch and treatment group were submitted, on ice, to the Udder Health Laboratory, University of Minnesota (St. Paul). The samples were thawed at room temperature and then underwent routine culture to determine TPC and TCC $(\mathrm{cfu} / \mathrm{mL})$. The second of each pair of frozen colostrum samples from the initial batch, postprocessing, and prefeeding samples from each batch and treatment group were sent to the Quality Control Laboratory of the Saskatoon Colostrum Company (Saskatoon, SK, Canada) for determination of colostrum IgG (g/L) levels by radial immunodiffusion analysis, as described by Chelack et al. (1993).

\section{Serum Sample Handling and Analysis}

All prefeeding (0-1 h) and postfeeding (24 h) blood samples were refrigerated overnight, allowing a clot to form. The next day, all blood samples were centrifuged at $11,952 \times g$ for $10 \mathrm{~min}$ at $20^{\circ} \mathrm{C}$ and the serum collected into duplicate storage cuvettes and labeled. A $1-\mathrm{mL}$ aliquot of serum was then frozen at $-20^{\circ} \mathrm{C}$ in an individual cuvette. Serum samples were transported on ice to the Quality Control Laboratory of the Saskatoon Colostrum Company to determine serum IgG $(\mathrm{mg} / \mathrm{mL})$ and serum total protein (STP, g/dL) levels by radial immunodiffusion analysis, as described by Chelack et al. (1993).

\section{Data Analysis}

Descriptive statistics were generated to describe colostrum characteristics for each of the 4 colostrum treatment groups being studied, including colostrum IgG concentration (g/L), colostrum TPC ( $\log _{10} \mathrm{cfu} /$ $\mathrm{mL})$, and TCC $\left(\log _{10} \mathrm{cfu} / \mathrm{mL}\right)$ after initial batch assembly, postprocessing, and prefeeding. Descriptive statistics were also generated to describe pre-enrollment calf characteristics for each of the 4 colostrum treatment groups including parity of dam, dystocia score (1-3), birth weight $(\mathrm{kg})$, age at feeding $(\mathrm{min})$, and calf serum $\operatorname{IgG}(\mathrm{mg} / \mathrm{mL})$ and STP $(\mathrm{g} / \mathrm{dL})$ concentrations at $0 \mathrm{~h}$.

Calf serum IgG $(\mathrm{mg} / \mathrm{mL})$, STP $(\mathrm{g} / \mathrm{dL})$, and apparent efficiency of absorption of IgG (AEA, \%) were also described at $24 \mathrm{~h}$ by treatment group. The AEA, a calculated measure that estimates the proportion of the total IgG mass fed absorbed into the calf's circulation, was calculated using a formula previously described by Quigley et al. (2002), assuming a plasma volume of $9.9 \%$ of birth weight.

Mixed linear regression analysis was conducted (Proc Mixed of SAS, version 9.3; SAS Institute Inc., Cary, $\mathrm{NC})$ to describe the effect of colostrum treatment group on each of the dependent variables describing colostrum characteristics (colostrum IgG, TPC, and TCC) and calf passive transfer measures (serum IgG, STP, and AEA \% at $24 \mathrm{~h}$ ). The explanatory variable of interest, colostrum treatment group (PU, DTB, FF, FR), was forced into each model. Additional covariates that were offered into the models (and controlled for if significant at $P<0.05$ ) included dam parity, birth weight $(\mathrm{kg})$, calving ease score (1-3), and time (min) at colostrum feeding. Batch number (1-31) was included as a random effect. Contrast analysis was used to make multiple comparisons of the various outcomes among the 4 treatment colostrum groups. Although final statistical significance was declared at $P<0.05$, the Bonferroni correction factor was applied to this $P$-value for all models involving multiple comparisons (Hochberg, 1988). 


\section{RESULTS AND DISCUSSION}

\section{Colostrum Characteristics}

Thirty-one unique batches of colostrum and 124 calves were initially enrolled into the study. However, 1 batch of colostrum was omitted from the final analysis of colostrum outcomes because of a missing prefeeding sample for the FR treatment group. As such, data from 30 unique batches were used for the final analysis of effect of treatment on colostrum characteristics.

Colostrum IgG Concentrations. Within the 4 treatment groups and across all 4 treatment groups, we detected no difference in IgG for any treatment group at the time of initial batch assembly, postprocessing, or prefeeding (Table 1). This demonstrates that IgG was not damaged during the heat treatment, freezing, or thawing and reheating processes. These results are consistent with previous studies that have reported heating colostrum at $60^{\circ} \mathrm{C}$ for 60 min using a batch pasteurizer does not affect IgG concentration (Johnson et al., 2007; Donahue et al., 2012).

Colostrum Bacterial Counts. We found no difference among treatments when evaluating the initial batch sample for TPC or TCC (Table 1). In postprocessing colostrum samples, TPC or TCC did not differ between FF or FR colostrum. Heat-treated colostrum (DTB and PU) had significantly lower TPC and TCC compared with fresh (FF and FR) colostrum. When comparing the heat-treated groups, DTB colostrum had a significantly lower TPC, but PU colostrum had significantly lower TCC (Table 1). In prefeeding colostrum samples, FR colostrum had significantly higher TPC and TCC than all other treatment groups. Prefeeding samples of heat-treated colostrum (DTB and PU) had significantly lower TPC and TCC compared with fresh (FF and FR) colostrum. Once again, when comparing the heat-treated colostrum groups, DTB colostrum had a significantly lower TPC, but PU colostrum had significantly lower TCC prefeeding (Table $=1)$. It is not clear why the DTB colostrum had a significantly lower TPC than the PU colostrum and the PU colostrum had a significantly lower TCC than DTB colostrum. However, both methods significantly reduced TPC and TCC compared with fresh colostrum, and these differences in bacteria counts between the DTB and PU in prefeeding colostrum may have been insignificant when the colostrum was fed to calves. The significant increase in bacterial counts in the FR colostrum from postprocessing to prefeeding reflected the bacterial proliferation that occurred during the refrigeration period, even though the average refrigeration time was only $21 \mathrm{~h}$ (up to $48 \mathrm{~h}$ ). Because we did not observe additional bacterial growth during storage in any of the frozen colostrum groups (DTB, $\mathrm{PU}$, or $\mathrm{FF}$ ), we recommend freezing excess colostrum that is not going to be fed within 1 to $2 \mathrm{~d}$ to prevent bacterial proliferation before feeding.

Table 1. Effect of treatment on colostrum characteristics ${ }^{1}$

\begin{tabular}{|c|c|c|c|c|}
\hline \multirow[b]{2}{*}{ Item } & \multicolumn{4}{|c|}{ Colostrum treatment group ${ }^{2}$} \\
\hline & $\begin{array}{l}\text { Perfect } \\
\text { Udder }\end{array}$ & $\begin{array}{l}\text { Dairy Tech } \\
\text { batch }\end{array}$ & $\begin{array}{l}\text { Fresh } \\
\text { frozen }\end{array}$ & $\begin{array}{l}\text { Fresh } \\
\text { refrigerated }\end{array}$ \\
\hline \multicolumn{3}{|l|}{ Colostrum IgG $(\mathrm{g} / \mathrm{L})$} & 30 & 30 \\
\hline $\begin{array}{l}\text { Colostrum } \lg \mathrm{G}(\mathrm{g} / \mathrm{L}) \\
\text { Initial batch }\end{array}$ & \multicolumn{4}{|c|}{$79.2(2.0)^{\mathrm{a}}$} \\
\hline Postprocessing & $77.7(2.0)^{\mathrm{a}, \mathrm{w}}$ & $77.7(2.0)^{\mathrm{a}, \mathrm{w}}$ & $79.2(2.0)^{\mathrm{a}, \mathrm{w}}$ & $79.2(2.0)^{\mathrm{a}, \mathrm{w}}$ \\
\hline & $78.3(2.0)^{\mathrm{a}, \mathrm{w}}$ & $77.0(2.0)^{\mathrm{a}, \mathrm{w}}$ & $79.5(2.0)^{\mathrm{a}, \mathrm{w}}$ & $78.2(2.0)^{\mathrm{a}, \mathrm{w}}$ \\
\hline \multicolumn{5}{|l|}{ Total plate count ( $\left.\log _{10} \mathrm{cfu} / \mathrm{mL}\right)$} \\
\hline Initial batch & \multicolumn{4}{|c|}{$5.3(0.2)^{\mathrm{a}}$} \\
\hline Postprocessing & $4.2(0.2)^{\mathrm{a}, \mathrm{w}}$ & $3.6(0.2)^{\mathrm{a}, \mathrm{x}}$ & $5.3(0.2)^{\mathrm{a}, \mathrm{y}}$ & $5.3(0.2)^{\mathrm{a}, \mathrm{y}}$ \\
\hline Prefeeding & $4.2(0.2)^{\mathrm{a}, \mathrm{w}}$ & $3.6(0.2)^{\mathrm{a}, \mathrm{x}}$ & $5.6(0.2)^{\mathrm{a}, \mathrm{y}}$ & $6.5(0.2)^{\mathrm{b}, \mathrm{z}}$ \\
\hline \multicolumn{5}{|l|}{ Total coliform count $\left(\log _{10} \mathrm{cfu} / \mathrm{mL}\right)$} \\
\hline Initial batch & \multicolumn{4}{|c|}{$3.8(0.2)^{\mathrm{a}}$} \\
\hline Postprocessing & $0.2(0.2)^{\mathrm{b}, \mathrm{w}}$ & $1.2(0.2)^{\mathrm{b}, \mathrm{x}}$ & $3.8(0.2)^{\mathrm{a}, \mathrm{y}}$ & $3.8(0.2)^{\mathrm{a}, \mathrm{y}}$ \\
\hline Prefeeding & $0.4(0.2)^{\mathrm{b}, \mathrm{w}}$ & $1.1(0.2)^{\mathrm{b}, \mathrm{x}}$ & $3.8(0.2)^{\mathrm{a}, \mathrm{y}}$ & $4.9(0.2)^{\mathrm{b}, \mathrm{z}}$ \\
\hline \multicolumn{5}{|c|}{${ }^{\mathrm{a} d}$ Values within column with different superscripts are significantly different $(P<0.05)$. } \\
\hline \multirow{2}{*}{\multicolumn{5}{|c|}{$\begin{array}{l}{ }^{\mathrm{w}-\mathrm{z}} \text { Values within row with different superscripts are significantly different (Bonferroni corrected } p \text { value } P< \\
0.0083 \text { ). }\end{array}$}} \\
\hline & & & & \\
\hline \multicolumn{5}{|c|}{${ }^{1}$ Values reported are adjusted means (SE). Models were adjusted for random effect of batch. } \\
\hline \multicolumn{5}{|c|}{$\begin{array}{l}{ }^{2} \text { Colostrum was heat-treated using the Perfect Udder Colostrum Management System (single aliquot; Dain } \\
\text { Tech Inc., Greeley, CO) or a commercial batch pasteurizer (Dairy Tech Inc.) or was not heat-treated (fresl } \\
\text { and either refrigerated or frozen before use. }\end{array}$} \\
\hline
\end{tabular}




\section{Passive Transfer of IgG in Calves}

Thirty-one calves were enrolled into each of the 4 colostrum treatment groups, for a total of 124 calves. Even though the study technician observed all births and investigators are certain that study calves did not nurse, data from 11 calves were omitted from the final analysis because they had 0-h (prefeeding) serum $\mathrm{IgG}>1.0 \mathrm{mg} / \mathrm{mL}$ to exclude the possibility that calves nursed before enrollment. This resulted in omitting data from $3,3,2$, and 3 calves from the PU, DTB, FF, and FR groups, respectively. Elevated 0 -h serum IgG values $(>1 \mathrm{mg} / \mathrm{mL})$ have been observed with a similar low frequency in studies conducted by these investigators on other commercial Midwest dairy farms (Godden et al., 2009). Apart from the possibility of nursing, alternate explanations could be that calves were exposed to pathogens in utero, resulting in seropositivity at birth (e.g., in utero congenital infection with bovine viral diarrhea virus) or that this is simply the result of analytical variation. Regardless of the reason, we are confident that these omissions did not introduce bias, in that they were evenly distributed among all study groups and study inferences were unchanged whether these calves were included or excluded from the analysis. Data from 1 additional calf were omitted from the FR group because of a missing prefeeding colostrum sample (Table 2).

Calf birth weights, dystocia scores, and time to feeding were not different among treatment groups (Table 2). Prefeeding serum IgG and STP concentrations were not different among the 4 treatment groups (Table 2). The quality $(\mathrm{IgG}, \mathrm{g} / \mathrm{L})$ and quantity $(3.8 \mathrm{~L})$ of colostrum fed to calves did not differ among treatment groups. Therefore, there was no difference among treatment groups in the total mass (g) of IgG fed (Table 2). There was a difference in cleanliness of colostrum, however, with the mean colostrum TPC and TCC being lower for calves in the PU and DTB groups compared with the FR and FF groups. Colostrum TPC and TCC levels were highest for calves fed FR colostrum (Table 2).

It took 60 min in a water bath at 48 to $51^{\circ} \mathrm{C}$ to thaw $3.8 \mathrm{~L}$ of frozen colostrum in the Perfect Udder bag to a feeding temperature of 37 to $40^{\circ} \mathrm{C}$. Warming refrigerated colostrum in the Perfect Udder bag to a feeding temperature of 37 to $40^{\circ} \mathrm{C}$ took approximately $20 \mathrm{~min}$ in the 48 to $51^{\circ} \mathrm{C}$ water bath. It is important to note this because underheating may result in delivery of cold colostrum. Overheating may be even more detrimental because it could result in damage to the oral, esophageal, or gastric mucosa if the colostrum is too hot when fed. Because heating to above $61^{\circ} \mathrm{C}$ is known to damage colostral $\operatorname{IgG}$, we recommend using a hot water bath set at 48 to $51^{\circ} \mathrm{C}$ to create a large margin of safety.

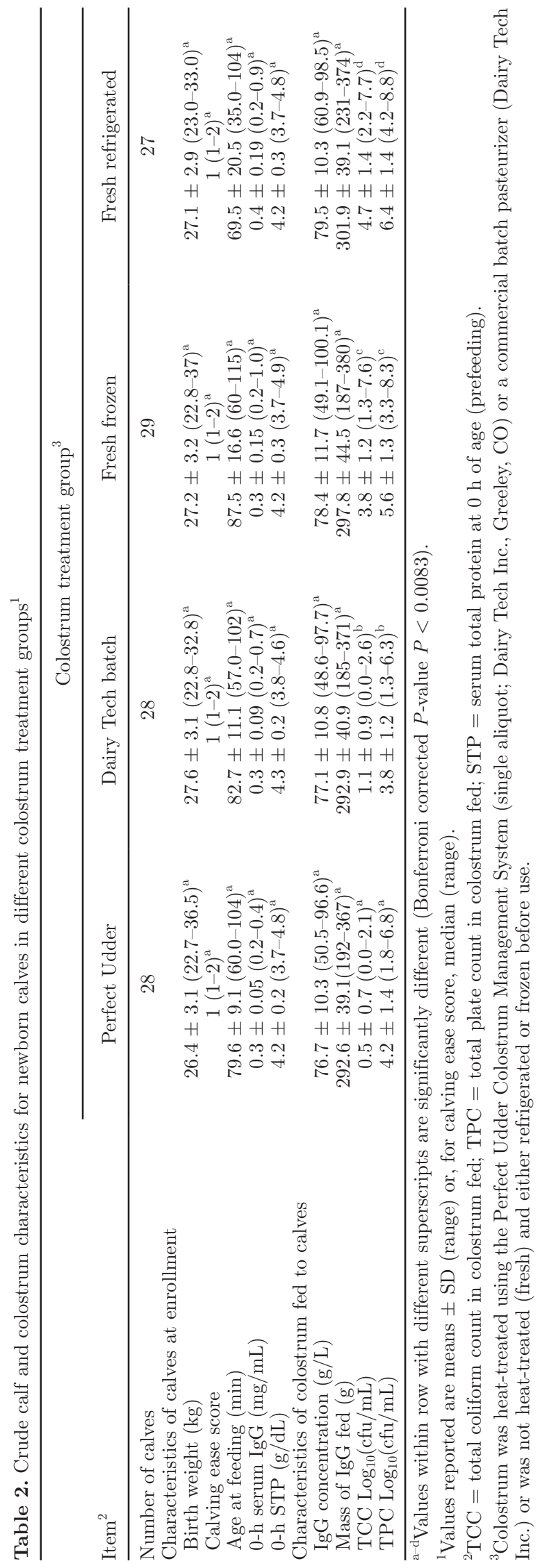

Journal of Dairy Science Vol. 98 No. 3, 2015 
Table 3. Effect of colostrum treatment on measures of passive transfer in calves ${ }^{1}$

\begin{tabular}{|c|c|c|c|c|}
\hline \multirow[b]{2}{*}{ Item $^{2}$} & \multicolumn{4}{|c|}{ Colostrum treatment group ${ }^{3}$} \\
\hline & $\begin{array}{l}\text { Perfect } \\
\text { Udder }\end{array}$ & $\begin{array}{c}\text { Dairy } \\
\text { Tech batch }\end{array}$ & & $\begin{array}{c}\text { Fresh } \\
\text { refrigerated }\end{array}$ \\
\hline $\begin{array}{l}\text { Number of calves } \\
24 \text {-h serum } \operatorname{IgG}(\mathrm{mg} / \mathrm{mL}) \\
\text { AEA IgG }(\%) \\
24 \text {-h STP }(\mathrm{g} / \mathrm{dL})\end{array}$ & $\begin{array}{l}28 \\
41.0(0.95)^{\mathrm{a}} \\
36.9(0.009)^{\mathrm{a}} \\
6.96(0.09)^{\mathrm{a}}\end{array}$ & $\begin{array}{l}28 \\
40.6(0.95)^{\mathrm{a}} \\
36.9(0.009)^{\mathrm{a}} \\
6.80(0.09)^{\mathrm{ab}}\end{array}$ & $\begin{array}{l}29 \\
35.1(0.93)^{\mathrm{b}} \\
31.9(0.009)^{\mathrm{b}} \\
6.46(0.09)^{\mathrm{b}}\end{array}$ & $\begin{array}{l}27 \\
35.5(0.97)^{\mathrm{b}} \\
32.3(0.009)^{\mathrm{b}} \\
6.51(0.09)^{\mathrm{b}}\end{array}$ \\
\hline \multicolumn{5}{|c|}{$\begin{array}{l}\text { a,b Values within row with different superscripts are significantly different (Bonferroni corrected } P \text {-value } P< \\
0.0083 \text { ). } \\
\text { the aliquot of colostrum fed, and random effect of batch. } \\
\text { }{ }^{1} \text { Values reported are adjusted means (SE). Models were adjusted for birth weight of calf, IgG concentration in } \\
{ }^{2} \mathrm{AEA}=\text { apparent efficiency of absorption of IgG at } 24 \mathrm{~h} \text {; STP = serum total protein at } 24 \mathrm{~h} \text { of age (postfeed- } \\
\text { ing). } \\
{ }^{3} \text { Colostrum was heat-treated using the Perfect Udder Colostrum Management System (single aliquot; Dairy } \\
\text { Tech Inc., Greeley, CO) or a commercial batch pasteurizer (Dairy Tech Inc.) or was not heat-treated (fresh) } \\
\text { and either refrigerated or frozen before use. }\end{array}$} \\
\hline
\end{tabular}

Calves fed heat-treated colostrum (DTB and PU) had significantly higher 24-h serum IgG concentrations compared with calves in the FF and FR groups (Table $3)$. When we applied the Bonferroni-corrected cut-point of $P<0.0083$ to account for multiple contrasts, calves fed PU colostrum had significantly higher 24-h STP concentrations compared with calves in the FF and FR groups. We detected no statistical difference in 24-h STP concentrations between the calves fed PU and DTB colostrum or among the calves fed DTB, FF, and FR colostrum (Table 3). We found no difference for either serum IgG or STP between the PU and DTB groups or between the FF and FR groups (Table 3 ). As birth weight, dystocia score, time to feeding, and mass of IgG fed were not different among heat-treated and fresh colostrum treatment groups, the likely explanation for higher serum IgG concentrations in calves fed heat-treated colostrum is probably the difference in AEA (\%), which was significantly greater in calves fed heat-treated colostrum (PU or DTB) compared with fresh colostrum (FF or FR; Table 3). These results are in agreement with earlier studies, which reported that the improvement in serum IgG when feeding heattreated colostrum was associated with improved AEA (Johnson et al., 2007; Elizondo-Salazar and Heinrichs, 2010). The increased AEA noted in the PU and DTB groups was associated with the decreased TCC (analysis not shown). This same relationship was noted in a previous study (Godden et al., 2012).

Of secondary interest, other covariates that were retained in the final models describing passive transfer outcomes included birth weight of the calf and quality of the aliquot of colostrum fed. Birth weight $(\mathrm{kg})$ had a negative association with serum IgG at $24 \mathrm{~h}$ [estimate $(\mathrm{SE})=-0.56(0.16), P=0.0007]$ but a positive as- sociation with AEA [estimate $(\mathrm{SE})=0.0067$ (0.0015), $P<0.0001]$. This suggests that larger calves absorbed IgG more efficiently but finished with a lower serum IgG concentration, perhaps due to a dilution effect by having a larger plasma volume. Calves fed higher quality (by $\operatorname{IgG}$ concentration) aliquots of colostrum had higher serum IgG concentrations [estimate $(\mathrm{SE})=0.33$ (0.045), $P<0.0001]$ and higher STP concentrations [estimate $(\mathrm{SE})=0.022(0.0044), P<0.0001$ ] at 24 $\mathrm{h}$, presumably because an increased total mass of IgG was available for absorption. However, being fed higher quality colostrum had a negative association with AEA [estimate $(\mathrm{SE})=-0.0014$ (0.0004), $P=0.0016]$, possibly due to a "saturation effect" in the small intestine.

In this study of Jersey calves, very high levels of passive transfer were achieved in all study groups, with overall average STP and serum IgG at $24 \mathrm{~h}$ being 6.7 $\mathrm{g} / \mathrm{L}$ and $38.0 \mathrm{mg} / \mathrm{mL}$, respectively. No calves in this study experienced failure of passive transfer, defined as a serum $\operatorname{IgG}<10 \mathrm{mg} / \mathrm{mL}$ at $24 \mathrm{~h}$ of age (McGuirk and Collins, 2004). These very high levels of passive transfer may be attributed to the fact that Jersey calves averaging $27.1 \mathrm{~kg}$ at birth were fed $3.8 \mathrm{~L}$ of high-quality colostrum (77.9 g/L IgG), resulting in an average of $296 \mathrm{~g}$ of $\operatorname{IgG}$ consumed per calf. Although feeding 3.8 L of high-quality colostrum in this study did result in exceptionally high serum IgG and STP levels, it may not be necessary to feed such large volumes to smallerbreed calves. Although all calves were clinically normal throughout the trial period, some temporary signs associated with discomfort (e.g., bawling or kicking) were observed when tubing 3.8 L into some calves. If highquality colostrum is fed early, then smaller volumes (10\% of BW) should be sufficient to achieve good levels of passive transfer in smaller breeds of calves. 


\section{CONCLUSIONS}

Heat-treating colostrum at $60^{\circ} \mathrm{C}$ for $60 \mathrm{~min}$, using either the Perfect Udder bag or batch pasteurizer system, resulted in a significant reduction of colostrum bacterial counts while maintaining colostrum IgG concentrations compared with fresh frozen or fresh refrigerated colostrum. Calves fed heat-treated colostrum (PU or DTB) experienced significantly improved AEA and higher final serum IgG and STP measures at 24 $\mathrm{h}$ of age compared with calves fed fresh ( $\mathrm{FF}$ or $\mathrm{FR}$ ) colostrum. When fresh colostrum was stored in a refrigerator, significant bacterial growth occurred even when the average storage time was less than $24 \mathrm{~h}$. Storing colostrum in the freezer prevented significant bacterial growth and did not negatively affect colostrum IgG concentrations.

\section{ACKNOWLEDGMENTS}

We thank the owners and staff at New Sweden Dairy (Saint Peter, MN) for their support of this study. Thanks, also, to the Saskatoon Colostrum Company for its assistance with colostrum and serum testing. This study was partially funded through a nonrestricted gift by Dairy Tech Inc. (Greeley, CO) and through the Department of Clinical and Population Sciences, College of Veterinary Medicine, University of Minnesota (St. Paul).

\section{REFERENCES}

Chelack, B. J., P. S. Morley, and D. M. Haines. 1993. Evaluation of methods for dehydration of bovine colostrum for total replacement of normal colostrums in calves. Can. Vet. J. 34:407-412.

Donahue, M., S. M. Godden, R. Bey, S. Wells, J. M. Oakes, J. Fetrow, S. Sreevatsan, and J. Stabel. 2012. Heat-treatment of colostrum on commercial dairy farms reduces colostrum microbial counts while maintaining colostrum immunoglobulin G concentrations. J. Dairy Sci. 95:2697-2702.
Elizondo-Salazar, J., and J. Heinrichs. 2010. Effect of heat-treated colostrum to neonatal dairy heifers: Effects on growth characteristics and blood parameters. J. Dairy Sci. 92:3265-3273.

Godden, S. M., D. M. Haines, and D. Hagman. 2009. Improving passive transfer of immunoglobulins in calves I: Dose effect of feeding a commercial colostrum replacer. J. Dairy Sci. 92:1750-1757.

Godden, S. M., D. J. Smolenski, M. Donahue, J. M. Oakes, R. Bey, S. Wells, S. Sreevatsan, J. Stabel, and J. Fetrow. 2012. Heat-treated colostrum and reduced morbidity in preweaned dairy calves: Results of a randomized trial and examination of mechanisms of effectiveness. J. Dairy Sci. 95:4029-4040.

Hochberg, Y. 1988. A sharper Bonferroni procedure for multiple tests of significance. Biometrika 75:800-802.

James, R. E., C. E. Polan, and K. A. Cummins. 1981. Influence of administered indigenous microorganisms on uptake of [iodine-125] gamma-globulin in vivo by intestinal segments of neonatal calves. J. Dairy Sci. 64:52-61.

Johnson, J., S. Godden, T. Molitor, T. Ames, and D. Hagman. 2007. The effect of feeding heat-treated colostrum on passive transfer of immune and nutritional parameters in dairy calves. J. Dairy Sci. 90:5189-5198.

McGuirk, S. M., and M. Collins. 2004. Managing the production, storage and delivery of colostrum. Vet. Clin. North Am. Food Anim. Pract. 20:593-603.

Morrill, K. M., E. Conrad, A. Lago, J. Campbell, J. Quigley, and H. Tyler. 2012. Nationwide evaluation of quality and composition of colostrum on dairy farms in the United States. J. Dairy Sci. 95:3997-4005.

Poulsen, K.P., F.A. Hartmann, and S.M. McGuirk. 2002. Bacteria in colostrum: Impact on calf health. Abstr. 52 (page 773) in Proc. 20th Am. Coll. Intern. Vet. Med., Dallas, TX. Mira Digital Publishing, St. Louis, MO.

Quigley, J. D. 3rd, C. J. Kost, and T. M. Wolfe. 2002. Absorption of protein and $\mathrm{IgG}$ in calves fed a colostrum supplement or replacer. J. Dairy Sci. 85:1243-1248.

Steele, M. L., W. B. McNab, C. Poppe, M. W. Griffiths, S. Chen, S. A. Degrandis, L. C. Fruhner, C. A. Larkin, J. A. Lynch, and J. A. Odumeru. 1997. Survey of Ontario bulk tank raw milk for foodborne pathogens. J. Food Prot. 60:1341-1346.

Streeter, R. N., G. F. Hoffsis, S. Bech-Nielsen, W. P. Shulaw, and D. M. Rings. 1995. Isolation of Mycobacterium paratuberculosis from colostrum and milk of subclinically infected cows. Am. J. Vet. Res. 56:1322-1324.

Walz, P. H., T. P. Mullaney, J. A. Render, R. D. Walker, T. Mosser, and J. C. Baker. 1997. Otitis media in preweaned Holstein dairy calves in Michigan due to Mycoplasma bovis. J. Vet. Diagn. Invest. 9:250-254 